\title{
Authoritarian Leadership and Extra-Role Behaviors: A Role-Perception Perspective
}

\author{
Yan Zhang ${ }^{1,2}$ and Yun-Hui Xie ${ }^{3,4}$ \\ ${ }^{1}$ Peking University, China, ${ }^{2}$ Bejing Key Laboratory of Behavior and Mental Health, China, ${ }^{3}$ China \\ Fianyin Investment Co., Ltd., China, and ${ }^{4}$ Bei Hang University, China
}

ABSTRAGT Authoritarian leaders make unilateral decisions and prevail over subordinates. Such leadership, as a style of exercising formal authority and position power, may inhibit employees' extra-role behaviors in the hierarchical role structure. We explore employees' role perceptions to better understand how supervisors' authoritarian leadership decreases extra-role behaviors $(\mathrm{OCBs})$. Authoritarian behavior is expected to generate subordinate perceptions of role conflict, role ambiguity, and role overload, with consequent negative effects on OCB. Hypotheses are tested using data from 613 subordinate - supervisor dyads. Empirical results indicate that authoritarian leadership increases subordinate role conflict and overload which then decreases OCB. Authoritarian behavior also increases role ambiguity, but role ambiguity is not associated with OCB. The article concludes with research suggestions and practical implications.

KEYWORDS authoritarian leadership, organizational citizenship behavior, role ambiguity, role conflict, role overload, supervisory behavior

\section{INTRODUGTION}

Supervisors use various leadership styles to exercise their formal authority and position power (Hoel \& Salin, 2003). Authoritarian leadership, as one such style, allows leaders to make unilateral decisions (Uhl-Bien \& Maslyn, 2005) and prevail over subordinates (Pelligrini, Scandura, \& Jayaraman, 2010). In response, subordinates will follow directions (Cheng, Chou, Wu, Huang, \& Farh, 2004) and adhere to job requirements or demands, but generally ignore discretionary extrarole behaviors (Bergeron, 2007). Thus some researchers believe that authoritarian leadership reduces employee organizational citizenship behavior (e.g., Chan, Huang, Snape, \& Lam, 2013; Chen, Eberly, Chiang, Farh, \& Cheng, 2014). Nevertheless, others suggest that authoritarian leadership has no direct effect 
(Aryee, Chen, Sun, \& Debrah, 2007; Wu, Huang, Li, \& Liu, 2012). Consequently, we ask, whether and how do authoritarian behaviors affect employee OCB?

Scholars have used social exchange and justice perspectives to explain how authoritarian leadership affects subordinate OCB. They have focused on the quality of leader - member social interactions, such as the quality of leader member exchange (Liang, Ling, \& Hsieh, 2007), trust in leaders (Chen et al., 2014; Wu et al., 2012), and interactional justice (Wu et al., 2012), failed to consider the hierarchical supervisor - subordinate structure that defines work roles for both parties regarding obligations, responsibilities, rights, performance expectations, and behavior patterns (Biddle, 1979). Assuming superior roles in the structure, supervisors may strongly shape subordinates' role perceptions, responsibilities, and work behaviors (Peterson et al., 1995).

Based on fundamental role structures in organizational hierarchies, we use role theory to explain how authoritarian behavior affects subordinate OCB. The theory posits that role structures generate role perceptions (Peterson et al., 1995). Supervisors, as role senders in supervisor - subordinate structures, define roles and create role expectations. Subordinates, as role receivers, are expected to follow the expectations. Furthermore, supervisor - subordinate structure allows supervisors to exercise power in an authoritarian manner. Subordinates may view authoritarian supervision as legitimate in-role supervisory behavior to frame or define organizational and job realities (Karambayya, Brett, \& Lytle, 1992; Smircich \& Morgan, 1982). Through work interactions, authoritarian supervisors are likely to shape subordinate perceptions regarding job realities, role expectations, and relevant behaviors. We suggest that authoritarian supervisors may affect subordinates' extra-role behaviors depending on how subordinates perceive their work roles: whether they perceive roles conflicting, ambiguous, or overloading (Katz \& Kahn, 1978; Rizzo, House, \& Lirtzman, 1970).

Authoritarian leadership depends on general organizational understandings regarding the nature of power, respect for authority, and behavioral expectations (Pye \& Pye, 2009), and role perceptions are rooted in organizational role structures (Peterson et al., 1995). Consequently, we believe that authoritarian leadership universally affects subordinate role perceptions and extra-role behavior in organizations across cultures. However, cultural viewpoints may differ regarding power distance and may determine whether authoritarian behavior is encouraged or inhibited (Robert, Probst, Martocchio, Drasgow, \& Lawler, 2000). Chinese culture strongly emphasizes power and hierarchy (Hofstede, 1980), so both Chinese supervisors and subordinates are more likely to legitimize authoritarian leadership (Saufi, Wafa, \& Hamzah, 2002). Consequently, China is a suitable research context for studying perceptions of roles and behaviors in relation to authoritarian leadership.

Our primary objective is to assess whether authoritarian leadership impacts subordinates' role perceptions and subsequent extra-role behaviors in China. We hope to show that leaders are role-makers affecting subordinates' role 
perceptions that mediates whether authoritarian leadership indirectly inhibits proorganizational behaviors.

We contribute to the literature in three important aspects. First, role perspectives offer new insights into how leadership behaviors affect subordinate work behaviors. Previous leadership studies focused on how leaders influence subordinate self-esteem (Chan et al., 2013), self-efficacy (Gong, Huang, Farh, 2009), job evaluations, including core job characteristics (Piccolo \& Colquitt, 2006), or attitudes towards supervisors such as trust (Chen et al., 2014), largely ignored how leaders influence subordinates' role perceptions. Consequently, we use a role perspective to explain how leadership affects subordinates.

Second, we integrate leadership and work role theories, and include leadership behaviors as determining work role perceptions. The literature has mainly considered role conflict, ambiguity, and overload as role stressors, and has investigated consequences such as emotional exhaustion, organizational commitment, job satisfaction, and job performance (see meta-analysis by Örtqvist \& Wincent, 2006), and lack of investigaing the determinants. Although scholars theorize that employees perceive their roles according to work events and supervisors' expectations in the role structure (Peterson et al., 1995), we propose that supervisory behaviors deliver social cues that may also affect their perceptions.

Moreover, rather than focusing on effective leadership behaviors, such as transformational leadership, we focus on traditional authoritarian leadership to explain whether and how such 'in-role' behavior may decrease extra-role behavior. If the relationship can be negative, the implications will be profound for managerial practice.

\section{THEORETICAL BACKGROUND AND HYPOTHESES}

\section{Authoritarian Leadership and Organizational Gitizenship Behavior}

Employee behaviors that contribute to 'the maintenance and enhancement of the social and psychological contexts that support task performance' are called organizational citizenship behaviors (OCBs) (Organ, 1997: 91). OCBs exceed job descriptions (Tepper \& Taylor, 2003) and are less likely to be rewarded or punished (Organ, Podsakoff, \& MacKenzie, 2006), although they benefit employees (Allen \& Rush, 1998), work groups (Podsakoff, Ahearne, \& MacKenzie, 1997), and organizations (Bolino, Turnley, \& Bloodgood, 2002). Supervisors largely affect subordinate discretionary behavior (Podsakoff, MacKenzie, Bachrach, 2000). For example, transformational leadership (Podsakoff, MacKenzie, Moorman, \& Fetter, 1990) and supervisory monitoring (Niehoff \& Moorman, 1993) are known to enhance OCB.

In contrast, authoritarian leadership emphasizes 'absolute authority and control over subordinates and demands unquestionable obedience from subordinates' (Cheng et al., 2004: 91). Authoritarian leaders strictly control the hierarchical order requiring subordinates to be submissive, dependent, and obedient (Pelligrini, 
Scandura, \& Jayaraman, 2010). They enforce rules, determine rewards and punishments (Aryee et al. 2007), and stress 'personal dominance' (Tsui, Wang, Xin, Zhang, \& Fu, 2004). Authoritarian leaders also make all important decisions (Tsui et al., 2004; Uhl-Bien \& Maslyn, 2005): assign tasks, give orders (Bond \& Hwang, 1993), and set high requirements (Cheng et al., 2004; Wang, Chiang, Tsai, Lin, \& Cheng, 2013). Under hierarchical structures, subordinates perceive that they must obey the legitimate dominance inherent in authoritarian leadership (Aryee et al., 2007), or else they must be punished. Consequently, they feel uneasy, oppressed, and often erupt in negative subordinate - supervisor social exchanges (Wu et al., 2012). Lacking socio-emotional benefits, they confine their behaviors to explicit inrole requirements to be 'good' workers but are unmotivated to work beyond their duties (Chen et al., 2014).

Literature has revealed that authoritarian leadership negatively affects subordinates. Early social psychology studies showed that authoritarian leadership increases spontaneous aggression and hostile behaviors (Lewin, Lippitt, \& White, 1939). Recent management studies suggested it reduces subordinate job satisfaction (Smither, 1993), organization-based self-efficacy (Chan et al., 2013), trust in leaders (Chen et al., 2014), interactional justice (Wu et al., 2012), voice (Chan, 2013; Li \& Sun, 2015), task performance, and conscientious behavior (Wang et al., 2013). Later contingency theories stated that specific contextual factors such as uncertainties (Rast III, Hogg, \& Giessner, 2013) may increase authoritarian leadership effectiveness (e.g., Vroom \& Yetton, 1973; Yukl, 2011), dependence and compliance (Chou, Sibley, Liu, Lin, \& Cheng, 2015), and productivity (Smither, 1993). Although authoritarian leadership may change employees' self-evaluations, justice judgment, and attitudes towards the leader and the job, we know little about the effects on their role perceptions.

\section{Role Theory and Role Perceptions}

Roles specify patterns of behaviors in various social contexts. In organizations, employees undertake work roles and use assigned obligations, rights, and performance expectations to guide their behavior and expectations regarding others' behaviors (Biddle, 1986). Role theory, concerning the study of the patterns of role behaviors (Biddle, 1979), is highly useful for studying individuals and the collective within a single conceptual framework and can thus help us better understand how organizational factors affect employees' job roles and behaviors.

As role theory suggests, job descriptions formally define work roles, but formal organizational policies and procedures, individual backgrounds and experiences, and treatment by coworkers and supervisors affect role perceptions (Peterson et al., 1995). Supervisors have legitimate power to redefine jobs, revise job requirements, change job characteristics, and provide job-related social cues when they evaluate work progress and output (Griffin, 1983). Therefore, immediate supervisors are 
role-makers and role-senders, shaping subordinate role perceptions (Peterson et al., 1995).

\section{Role Perceptions as Mediating Mechanisms}

Supervisors send various work expectations and social cues to subordinates (Dale \& Fox, 2008). As role theory states, when expectations are unclear, conflicted, or overwhelming, employees then perceive their work roles to be ambiguous, conflicting, or overloaded (Katz \& Kahn, 1978; Rizzo et al., 1970). The negative perceptions then affect their work attitudes and behaviors (Jex, 1998; Thompson \& Werner, 1997) such as job satisfaction (Johnston, Parasuraman, \& Futrell, 1989), emotional exhaustion (Örtqvist \& Wincent, 2006), and job performance (Tubre \& Collins, 2000). We expect that authoritarian leadership will cause employees to perceive conflict, ambiguity, and overload in their roles, with consequent negative effects on employee OCB.

\section{Role Conflict as a Mediating Mechanism}

Role conflict is 'incompatibility between the expectations of parties or between aspects of a single role' (Peterson et al., 1995: 430). Employees experience role conflict when they undertake several roles requiring different behaviors, when they are confronted with incompatible expectations from multiple persons or standards, or when they perceive that role expectations and requirements conflict with their internal standards, values, time, resources, or capabilities (Katz \& Kahn, 1978; Rizzo et al., 1970).

Authoritarian supervisors may provoke acute perceptions of role conflict by making unilateral decisions and centralizing authority on themselves (Tsui, Wang, Xin, Zhang, \& Fu, 2004). To make decisions independently and highlight their authority, they control resources and rules (Chan, 2013) while tightly withholding or even concealing key information (Cheng \& Wang, 2015; Farh \& Cheng, 2000; Wang et al., 2013). Simultaneously, they insist on adherence to high work standards (Wang et al., 2013). Subordinates are then conflicted: they lack work-relevant information and resource support but are expected to meet high expectations.

Second, authoritarian leaders tend to make decisions unilaterally, maintaining supervisor/subordinate distance (Aryee et al., 2007) and striving to enhance their personal status (Schuh, Zhang, \& Tian, 2013). They believe that they know more than other employees (Ertureten, Cemalcilar, \& Aycan, 2013), so they can ignore, disrespect, devalue, and discount subordinates' suggestions and contributions (Aryee et al., 2007). Their controlling behaviors further signal strong disregard for subordinates' interests, perspectives and abilities (De Cremer, 2006; Foels, Driskell, Mullen, \& Salas, 2000), which then impairs their sense of competence and selfevaluation (Chan et al., 2013). Employees feel devalued and discouraged, while 
pressured to meet high work standards. The incompatible expectations produce role conflicts. We propose:

Hypothesis 1a: Supervisors' authoritarian behaviors will positively affect subordinates' role conflict.

Under high role conflict, subordinates may spend much work time struggling to balance incompatible expectations. The pressure generates psychological strain such as increased depression and frustration (Beehr, Jex, Stacy, \& Murray, 2000; Jex \& Beehr, 1991). Employees may feel exhausted and lack cognitive and emotional resources (Lankau, Carlson, \& Nielson, 2006) to perform discretionary activities. Instead, they must focus on mandatory tasks (Thompson \& Werner, 1997), directly aligning their behavior with the evaluation standards or explicit requirements (Bergeron, 2007; Eatough, Chang, Miloslavic, \& Johnson, 2011). In summary, subordinates under authoritarian supervisors will suffer role conflict and will be less likely to perform OCB:

Hypothesis 1b: Subordinates' role conflict will mediate the relationship between supervisors' authoritarian behaviors and subordinates' $O C B$. Authoritarian behaviors will positively affect role conflict; role conflict will further negatively affect $O C B$.

\section{Role Ambiguity as a Mediating Mechanism}

Role ambiguity is 'uncertainty about what actions to take to fulfill a role' (Peterson et al., 1995: 430). When role senders fail to define or communicate role expectations clearly, employees have unclear expectations and consequently perceive role ambiguity (Kahn, Wolfe, Quinn, \& Snoek, 1964; Katz \& Kahn, 1978; Lyons, 1971).

Authoritarian supervisors may increase subordinates' perceptions of role ambiguity. They withhold important information and resources (Chan, 2013; Wang et al., 2013) for control, subordinates feel they cannot get work support. Simultaneously supervisors set high standards and deliver error-free expectations. The hierarchical distance prevents subordinates from explicitly dissenting or daring to seek help (Chan et al., 2013; Farh \& Cheng, 2000; Flood et al., 2000; Pellegrini $\&$ Scandura, 2008). They are unclear about how to reach high standards.

Moreover, authoritarian leadership allows little room for subordinates to perform their assigned roles independently and autonomously. With independence and autonomy, can subordinates ignore obscure or vague messages, modify or even redefine their roles according to their own expectations (Jackson \& Schuler, 1985; Shenkar \& Zeira, 1992). Conversely, authoritarian leaders demand unquestioned obedience, compliance, and dependence (Chan, 2013), so employees must accept and process ambiguous information:

Hypothesis 2a: Supervisors' authoritarian behaviors will positively affect subordinates' role ambiguity. 
Subordinates who are uncertain about job expectations are uncertain about the extent of their own authority or the standards that will be used to judge them. They experience anxiety, depression, and futility that lower their self-esteem (Jackson \& Schuler, 1985; Van Sell, Brief, \& Schuler, 1981), so they avoid job involvement. Instead, they rely on passive trial-and-error approaches for meeting supervisor expectations (Rizzo et al., 1970), perhaps without knowing that they are working counterproductively from the organizational perspective (Van Sell et al., 1981). Role ambiguity is known to reduce voluntary efforts to do quality work (Beehr, Walsh, \& Tabler, 1976, Van Sell et al., 1981). Hence, we expect authoritarian supervisors may cause more role ambiguity and further reduce OCB:

Hypothesis 2b: Subordinates' role ambiguity will mediate the relationship between supervisors' authoritarian behaviors and subordinates' OCB. Authoritarian behaviors will positively affect role ambiguity, and role ambiguity will further negatively affect $O C B$.

\section{Role Overload as a Mediating Mechanism}

Role overload describes 'lack of the personal resources needed to fulfill commitments, obligations, or requirements' (Peterson et al.: 430). It occurs when employees perceive that they have too many responsibilities compared with their time, resources, abilities, and other constraints; when they are overwhelmed by role demands exceeding the available resources; or when they are confronted by multiple role senders with various expectations (Rizzo et al., 1970; Singh, 2000).

Authoritarian supervisors may increase role-overload perceptions by centralizing work decisions and requiring high performance without excuses, exceptions, or subordinate participation in decision-making (Tsui et al., 2004). Lacking adequate information exchange, subordinates cannot tell supervisors about practical problems they face in completing work assignments. Supervisory control of information and resources further exacerbates their practical difficulties. Even worse are the high performance standards (Cheng et al., 2004) without bilateral communications that would allow supervisors to know whether subordinates have the ability, time, and resources to meet expectations. Moreover, authoritarian supervisors transmit salient information cues that employees lack job autonomy (Chan et al., 2013) and must obey without question. Employees are then less likely to seek help from supervisors and other outside resources. Consequently, they feel overloaded:

Hypothesis 3a: Supervisors' authoritarian behaviors will positively affect subordinates' role overload.

From a resource allocation perspective, overloaded and overwhelmed employees (Bolino \& Turnley, 2005) must spend significant time and resources to alleviate overload perceptions and assure in role performance. Consequently, role overload may reduce their sense of achievement and confidence (LePine, Podsakoff, \& LePine, 2005). Subordinates are less satisfied with their jobs (Eatough et al., 2011), 
and demotivated to perform discretionary extra-role efforts (Bergeron, 2007). Thus:

Hypothesis 3b: Subordinates' role overload will mediate the relationship between supervisors' authoritarian behaviors and subordinates' $O C B$. Authoritarian behaviors will positively affect role overload, and role overload will further negatively affect $O C B$.

\section{METHOD}

\section{Sample and Procedure}

We collected leader - subordinate paired data from seven technical support and service private companies in North China, whose businesses include e-business, Internet technology, telecommunications, wind power products, and insurance. All the companies have formal hierarchical organizational structures. Participants included all supervisors and their subordinates in the same teams in a large company unit/branch. The teams engage in technical work or consumer service. Contact persons in each firm provided information about participating employees and their immediate supervisors, which allowed us to develop codes to match them. The contact persons administered paper surveys onsite. Respondents returned completed surveys in sealed, preaddressed envelopes to ensure confidentiality.

We surveyed participants twice because temporal separation between an independent variable and mediation variables allows previously recalled information to leave short-term memory (Podsakoff, Mackenzie, Lee, \& Podsakoff, 2003). At time 1, subordinates rated supervisors' authoritarian leadership and their demographic information. After three weeks, a time lag that is long enough to eliminate short-term memory influence but will not mask pre-existing relationships (Gong et al., 2009; Podsakoff et al., 2003), they reported their role perceptions and control variables (leader - member exchange and procedural justice perceptions), and their supervisors assessed their OCB. We distributed 786 employee questionnaires; 731 were returned at time one; 722 were returned at Time 2; 705 returned both questionnaires (a response rate of 89.7). We excluded those who missed first- or second-time data and excluded invalid questionnaires such as those missing a majority of blanks, giving all items the same scores, or showing zigzag patterns, for a final sample of 613 subordinates. Each supervisor had an average of 6.19 subordinates $(\mathrm{SD}=2.59)$.

In the subordinate sample, 59.6 percent were men; 87.3 percent had college or above education. The mean age was $27.6(S D=6.60)$ and mean organizational tenure was $2.2(S D=2.08)$ years.

\section{Measures}

We used a five-point Likert-type scale for the questionnaires: $1=$ strongly disagree and $5=$ strongly agree. All relevant variables used measures that had good reliabilities 
in previous literature. For the English-version measures, we generated Chinese versions following the translation-back-translation procedure (Brislin, 1980).

Authoritarian leadership. Following Zhang, Tsui, and Wang (2011), we used five items to measure supervisors' authoritarian behavioral tendency to make directive decisions and maintain hierarchical order: 'My supervisor has personal control of most matters', 'My supervisor centralizes decision on him/herself', 'My supervisor makes unilateral decisions and takes individual actions', 'My supervisor always behaves commandingly in front of employees', 'We must follow his/her rules to get things done. If not, he/she punishes us severely'. Cronbach's alpha was 0.92 .

Role perceptions. We adopted role perception measurements from Peterson et al.'s (1995) scale based on role conflict, role ambiguity (Rizzo et al., 1970), and role overload scales (Pareek, 1976). For role conflict we used three items 'I often get involved in situations in which there are conflicting requirements', 'I receive incompatible requests from two or more people', 'I have to do things that should be done differently under different conditions'. For role ambiguity we used five reverse-coded items: 'I (do not) have clear planned goals and objectives for my job', 'I (do not) have clear planned goals and objectives for my job', 'I (do not) know exactly what is expected of me', 'I (do not) know what my responsibilities are', 'I (do not) feel certain about how much responsibility I have', 'My responsibilities are (not) clearly defined'. For role overload we used five items: 'There is a need to reduce some parts of my role', 'I feel overburdened in my role', 'I have been given too much responsibility', 'My work load is too heavy', 'The amount of work I have to do interfere with the quality I want to maintain'. Cronbach's alpha coefficients were $0.92,0.89$, and 0.87 , respectively.

$O C B$. We adopted a 15-item scale from Song, Tsui, and Law (2009). For example, 'He/she is willing to help new employees adapt to the environment though it's not part of his/her job' and 'He/She is willing to help his/her colleagues with their work problems'. Cronbach's alpha coefficient was 0.91 .

Control variables. We controlled for leader - member exchange and procedural justice perceptions because they reflect two alternative mechanisms for explaining how authoritarian leadership affects subordinate OCB (Liang et al., 2007; Wu et al., 2012). We adopted a seven-item scale (Scandura \& Graen, 1984) to measure leader - member exchange. For example, 'I feel that my immediate supervisor recognizes my potential' and 'I feel that my immediate supervisor understands my problems and needs at work'. Cronbach's alpha coefficient was 0.92. We adapted a four-item scale from Moorman (1991) to measure procedural justice: 'My supervisor makes job decisions in an unbiased manner', 'My supervisor provides opportunities to appeal or challenge job decisions', 'My supervisor explains why decisions are made', 'My supervisor has developed procedures designed to generate 
standards so that decisions could be made with consistency'. Cronbach's alpha coefficient was 0.92 . We used a five-point Likert scale from $1=$ strongly disagree to $1=$ strongly agree for the two measures. We also controlled for age, gender, and job types because they affect work perceptions and behaviors (e.g., Chen et al., 2014; Wu et al., 2012). Age was measured in years. Gender was a categorical variable with 1 for women and 0 for men. Job type was a categorical variable with 1 for technical work and 0 for consumer service work. Seven of the firms differ in their business and organizational characteristics, but their teams focus mainly on one job type. To avoid multicollinearity, we controlled only for job type.

\section{Analyses}

We used Mplus 7.31 to examine the hypothesized model. To account for the nonindependence in OCB ratings, we used MSEM because it accounts for hierarchical data and avoids inaccurate standard errors and biased statistical conclusions because of non-independence (Bliese, 2000). We treated our dyadic-level research constructs at the individual level and controlled team identity at the team level.

Before we conducted confirmatory factor analysis and tested the structural models, we averaged items into OCB dimensions and treated the dimension scores as separate indicators of OCB. In addition, we randomly assigned the items into three parcels for each unidimensional latent variable with more than three items, namely authoritarian leadership, role overload, and role ambiguity, because parcels have psychometric merits relative to items and are particularly effective for unidimensional constructs (Little, Cunningham, Shahar, \& Widaman, 2002) and such approach can maximize the degree of freedom and avoid model identification problems (Hau \& Marsh, 2004). We then used item scores as indicators of role conflict because it has only three items. Thereafter we did confirmative factor analysis to test the construct validity, ran the hypothesized structural model and alternative models, and compared model fit indices to evaluate model fit (Bollen, 1989; Kelloway, 1998). Next, we reported the indirect effects for mediating hypotheses, which, in Mplus, is estimated using maximum-likelihood and is based on counterfactuals (causal inference). Potential outcomes using expectations were previously developed (c.f., Muthén, 2011; Pearl, 2001; Robins, 2003; Robins \& Greenland, 1992).

\section{RESULTS}

\section{Correlation Results}

Table 1 summarizes means, standard deviations, correlations, and reliability coefficients (Cronbach's alpha) of all the variables. Authoritarian behavior was negatively associated with OCB $(r=-0.15, p<0.01)$ and positively associated with role conflict $(r=0.35, p<0.01)$, role ambiguity $(r=0.16, p<0.01)$, and role overload $(r=0.39, p<0.01)$. Role conflict, role ambiguity, and role overload were 
Table 1. Descriptive statistics and zero-order correlations $(\mathrm{N}=613)$

\begin{tabular}{|c|c|c|c|c|c|c|c|c|c|c|c|}
\hline Variables & Mean & $S D$ & 1 & 2 & 3 & 4 & 5 & 6 & 7 & 8 & 9 \\
\hline 1. subordinate age & 27.58 & 6.60 & - & & & & & & & & \\
\hline 2. subordinate gender & 0.60 & 0.49 & $-0.17^{* *}$ & - & & & & & & & \\
\hline 3. leader member exchange & 4.29 & 0.90 & $-0.15^{* *}$ & $0.12^{* *}$ & $(0.92)$ & & & & & & \\
\hline 4. procedural justice perception & 4.61 & 1.00 & $-0.18^{* *}$ & $0.08^{*}$ & $0.43^{* *}$ & $(0.92)$ & & & & & \\
\hline 5. authoritarian leadership & 2.95 & 1.25 & $0.17^{* *}$ & $-0.12^{* *}$ & $-0.22^{* *}$ & $-0.18^{* *}$ & $(0.95)$ & & & & \\
\hline 6. role overload & 2.69 & 0.94 & $0.29^{* *}$ & $-0.11^{* *}$ & $-0.24^{* *}$ & $-0.27^{* *}$ & $0.35^{* *}$ & $(0.92)$ & & & \\
\hline 7. role ambiguity & 1.98 & 0.75 & $0.09^{*}$ & -0.00 & $-0.25^{* *}$ & $-0.43^{* *}$ & $0.16^{* *}$ & $0.22^{* *}$ & $(0.89)$ & & \\
\hline 8. role conflict & 2.74 & 1.03 & $0.12^{* *}$ & $-0.10^{*}$ & $-0.14^{* *}$ & $-0.18^{* *}$ & $0.39^{* *}$ & $0.49^{* *}$ & $0.19^{* *}$ & $(0.87)$ & \\
\hline 9. subordinate OCB & 4.38 & 0.71 & $-0.21^{* *}$ & $0.18^{* *}$ & $0.12^{* *}$ & $0.11^{* *}$ & $-0.15^{* *}$ & $-0.24^{* *}$ & $-0.09^{*}$ & $-0.22^{* *}$ & $(0.91)$ \\
\hline
\end{tabular}

Note: $* p<.05, * * p<.01$; numbers in the bracket are Cronbach alpha reliability; OCB $=$ organizational citizenship behavior. 
Table 2. Comparison of measurement models $(\mathrm{N}=613)$

\begin{tabular}{lrrrrrrrr}
\hline \hline Models & $\chi^{2}$ & $\mathrm{df}$ & $\chi^{2} / \mathrm{df}$ & $\Delta \chi^{2}(\Delta \mathrm{df})$ & CFI & TLI & RMSEA & SRMR \\
\hline Five-factor model & 627.24 & 185 & 3.39 & & 0.94 & 0.93 & 0.06 & 0.06 \\
$\begin{array}{l}\text { Four-factor model: } \\
\text { Combining RC \& }\end{array}$ & 1431.46 & 189 & 7.48 & $804.22(4)$ & 0.83 & 0.81 & 0.10 & 0.09 \\
$\quad$ & & & & & & & & \\
$\quad \begin{array}{l}\text { RA } \\
\quad \text { Combe-factor model: }\end{array}$ & 3468.14 & 192 & 18.06 & $2840.90(7)$ & 0.54 & 0.50 & 0.17 & 0.15 \\
$\quad \begin{array}{l}\text { RA and RO } \\
\text { Two-factor model: } \\
\text { Combining AB, } \\
\quad \text { RC, RA and RO }\end{array}$ & 5385.08 & 194 & 27.76 & $4757.84(9)$ & 0.28 & 0.22 & 0.21 & 0.18 \\
\begin{tabular}{l} 
One-factor model \\
\hline \hline
\end{tabular} & 5596.24 & 195 & 28.70 & $4969.00(10)$ & 0.25 & 0.19 & 0.21 & 0.19 \\
\hline
\end{tabular}

Note: $* * * p<.001 . \mathrm{AB}=$ authoritarian behavior; $\mathrm{RO}=$ role overload; $\mathrm{RA}=$ role ambiguity; $\mathrm{RC}=$ role conflict; $\mathrm{OCB}=$ organizational citizenship behavior.

each significantly correlated with OCB $(r=-0.24, p<0.01 ; r=-0.09, p<0.05$; $r=-0.22, p<0.01)$. Those correlations preliminarily aligned with the hypotheses.

\section{GFA Results}

We used multilevel confirmatory factor analysis (MCFA) to test the construct distinctiveness between authoritarian leadership, role conflict, role ambiguity, role overload, and OCB (Table 2). The hypothesized five-factor model had a good fit with all the fit indices at the acceptable level $\left(\chi^{2}=627.24, d f=185, \chi^{2} / d f=3.39\right.$, $C F I=0.94, T L I=0.93, R M S E A=0.06)$. To check the discriminant validity of the hypothesized five-factor measurement model, we compared it with four alternative models. In the four-factor model, role conflict and role overload were merged into one factor $\left(\Delta \chi^{2}(4)=804.22, p<0.01\right)$. In the three-factor model, three role perceptions were merged into one factor $\left(\Delta \chi^{2}(7)=2840.90, p<0.01\right)$. In the two-factor model, authoritarian behavior was combined with the three role stresses $\left(\Delta \chi^{2}(9)=4757.84, p<0.01\right)$. In the one-factor model, all five variables were combined as one factor $\left(\Delta \chi^{2}(10)=4969.00, p<0.01\right)$. Based on those results, we concluded that the five-factor model showed better fit with data.

\section{SEM Results}

We ran a full mediation model: supervisors' authoritarian behavior affected subordinate OCB fully through three role perceptions. It had good fit indices: $\chi^{2}=$ 1546.36, $d f=501, \chi^{2} / d f=3.09, C F I=0.91, T L I=0.90, R M S E A=0.06, S R M R$ $=0.08$. We also ran a nested partial mediation model, adding a direct path from authoritarian behavior to subordinate OCB. The fit indices were $\chi^{2}=1546.23$, $d f=500, \chi^{2} / d f=, C F I=0.91, T L I=0.90, R M S E A=0.06, S R M R=0.08$. The partial mediation model was not significantly better than the full mediation 


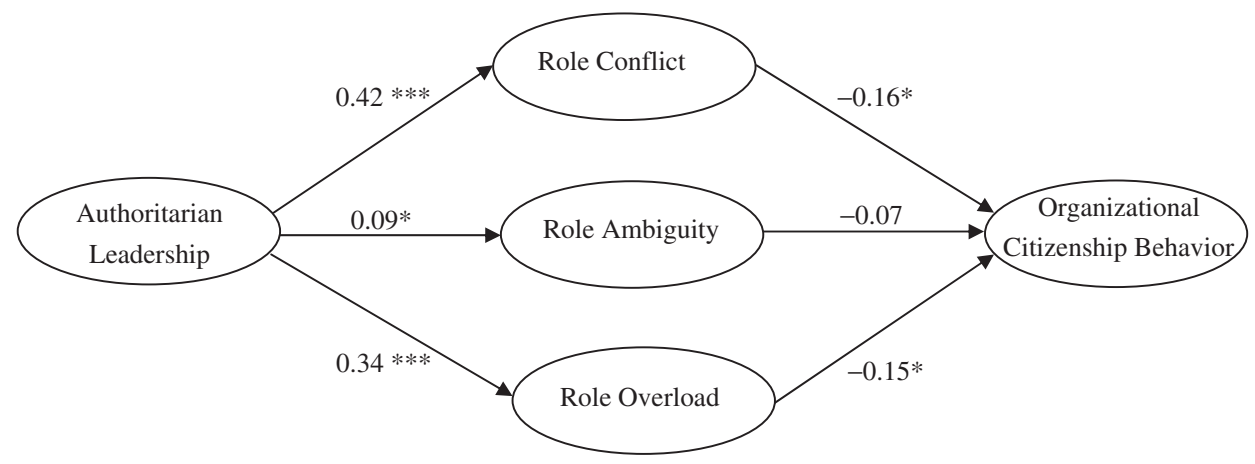

Figure 1. The structural model of authoritarian leadership, role perceptions, and OCB Note: $* p<0.05, * * p<0.01, * * * p<0.001$.

model $\left(\Delta \chi^{2}(1)=0.13, p<0.05\right)$, so we used the full mediation model to test the hypotheses following the parsimony principle (see Figure 1).

In the full mediation model, the standardized estimates of the paths from authoritarian behavior to role conflict, to role ambiguity, and to role overload were $0.42(p<0.001), 0.09(p<0.05)$ and $0.34(p<0.001)$, supporting H1a, H2a, and $\mathrm{H} 3 \mathrm{a}$ respectively. The path estimates from role conflict, role ambiguity, and role overload to OCB were $-0.16(p<0.05),-0.07$ (n.s.) and $-0.15(p<0.01)$, demonstrating that both role conflict and role overload were negatively related with $\mathrm{OCB}$, and role ambiguity was insignificant to OCB. Thus Hypothesis $2 \mathrm{~b}$ was rejected.

To test the mediation hypotheses ( $\mathrm{H} 1 \mathrm{~b}$ and $\mathrm{H} 3 \mathrm{~b}$ ), we examined the indirect effects. Particularly, the indirect effect mediated by role conflict from authoritarian behavior to $\mathrm{OCB}$ was $-0.067, p<0.05$ supporting $\mathrm{H} 1 \mathrm{~b}$. The indirect effect mediated by role overload was $-0.050, p<0.05$, supporting H3b.

\section{DISGUSSION}

In this study, we propose that authoritarian supervisors cause employees to perceive their job roles as conflicted, ambiguous, and overloaded, with consequent negative effects on their OCB. We find that role conflict and overload perceptions, but not role ambiguity, are significant mediators. We conclude that role perceptions greatly explain the influences of authoritarian behavior on subordinates' OCB in Chinese organizations.

Unexpectedly, perceptions of role ambiguity did not affect employee OCB in SEM results. Nevertheless, the two were negatively associated in the correlation analysis $(r=-0.09, p<0.05)$. The structural model simultaneously considers the effects of the three role perceptions on the dependent variable. Compared with role conflict and role overload, role ambiguity has a weaker association with OCB and a moderately high correlation with role conflict $(r=0.49, p<0.001)$. Thus role conflict effects may partial out role ambiguity effects on OCB. 


\section{Theoretical Contribution}

Our role perspective contributes to leadership and OCB literature by exploring whether role conflict, overload, and ambiguity perceptions mediate authoritarian leadership effects on extra-role behaviors. First, leadership scholars have predominantly focused on characteristics or behaviors of effective/successful leaders (Hunter, Bedell-Avers, \& Mumford, 2007), but have largely ignored how authoritarian leadership may negatively affect subordinates, and have rarely considered the authoritarian style rooted in supervisory roles. Making unilateral decisions and maintaining hierarchical distance even become regular supervisory role activities, but simultaneously produce subtle social influences on subordinates. Our research deepens our understanding of how authoritarian leadership affects subordinates.

We confine our investigation to authoritarian supervision to show that authoritarian supervision indirectly harms OCB through complex role-making processes. The role perspective will help scholars better understand how leadership shapes role perceptions and resulting extra-role behaviors. Leaders who set high requirements and act as superiors in their leadership roles ensure that subordinates see themselves as playing lower roles; they are forced to focus too much on their in-role responsibilities and ignore extra-role work (Bergeron, 2007).

Third, we provide insights into work role literature by proposing that leadership helps to determine role perceptions. The role-stress literature has mainly considered role conflict, ambiguity, and overload as exogenous forces, and rarely considered their predictors. However, work events, and senders' expectations do not cause negative role perceptions in isolation (Peterson et al., 1995). Supervisory behavior also sends powerful social informational cues. By linking the leadership and role stress literature, we show a new way to understand how organizational leaders can interpersonally amend role perceptions.

\section{Practical Implications}

This research provides practical implications for organizational management. Unilateral decision-making and hierarchical distance conveys authoritarian style leadership which then negatively affects employees' role perceptions. To counterbalance such effects, leaders might consult with subordinates before making decisions, obtain their input, and explain reasons for higher-level decisions. Firms may also want to design and implement leadership programs that train supervisors in leadership skills beyond authoritarianism. To increase role clarity and decrease role conflict and overload, firms should comprehensively analyze and clearly define jobs so that supervisors will have less negative social influence on subordinate work role perceptions. If subordinates are clear about in-role requirements, they may be more likely to perform extra-role behaviors. 


\section{Limitations and Future Research Directions}

This study has several limitations that provide suggestions for future research directions. We conducted our study in China and should be cautious about generalizability. Although authoritarian leadership is a form of paternalistic leadership, the style is universal (Pelligrini \& Scandura, 2008). Because of the Western cultural emphasis on equality, authoritarian leadership may be less popular in Western countries. Nevertheless, Western supervisors must make final decisions and maintain certain position status. Consequently, authoritarianism might have more salient effects on role perceptions in the West because employees are sensitive to unequal treatments. Future research can compare whether the current research model is more salient in Western contexts.

Second, focusing only on authoritarian leadership may narrow our lens to a pure negative aspect. Indeed, other leader behaviors approach power differently, and have different effects on role perceptions. For example, transactional supervisors 'clarify the role and task requirements for followers' (Bass \& Avolio, 1990: 236). By increasing job clarity, they reduce role conflict (MacKenzie, Podsakoff, \& Rich, 2001). Another supervisory behavior - initiating structure - also reduces role stress and ambiguity (Dale \& Fox, 2008). Future research should further demonstrate that role perceptions are important consequences of leadership behaviors. Moreover, the research might investigate conditions that will allow authoritarian leaders to cause less role conflict, overload, and ambiguity. For example, benevolent leadership may buffer the negative effects on role perceptions. When subordinates are highly traditional, older, or have more work experience, they may be more likely to accept authoritarian behavior and less likely to have negative role perceptions.

Third, we used OCB to represent extra-role behavior. We did not consider alternative proactive, voice, and creative behavior because we do not expect authoritarian leadership to similarly influence those behaviors. For example, high work expectations but low work resources and support may force subordinates to creatively accomplish their tasks. Future research could investigate whether incompatible situations may trigger creativity.

Fourth, we proposed cognitive overload, information processing, and emotional exhaustion in explaining how role perceptions affect OCB, but did not test those mechanisms. Future research could empirically investigate whether they mediate between role perceptions and OCBs.

Fifth, methodologically, we failed to separately collect role perceptions and OCB variables although they come from different sources. Ideally, time lags should occur between measures of supervisory behavior, role perceptions, and OCB. Nevertheless, the findings align with our logic so our results may still be valid. For example, we assume that increasing role overload reduces OCB, and empirical results show a negative relationship, but $\mathrm{OCB}$ has empirically been shown to increase role overload (Bolino \& Turnley, 2005). Additionally, our questionnaire surveys may have caused mono-method bias and may fail to show causal relationships. 


\section{GONGLUSION}

Supervisory behaviors greatly determine subordinate performance. Companies in China's rapidly changing and highly competitive environment are especially pressed to discover the most effective management styles. Our study contributes to the leadership literature by identifying how China's typically authoritarian supervisors affect subordinates' role perceptions and their consequent OCB.

\section{NOTES}

The two authors contributed equally to this paper. This research was funded by the National Natural Science Foundation of China (grant number 71372022, 71522005).

\section{REFERENCES}

Allen, T. D., \& Rush, M. C. 1998. The effects of organizational citizenship behavior on performance judgments: A field study and laboratory experiment. Journal of Applied Psychology, 83(2): 247-260.

Aryee, S., Chen, Z. X., Sun, L. Y., \& Debrah, Y. A. 2007. Antecedents and outcomes of abusive supervision: Test of a trickle-down model. Journal of Applied Psychology, 92(1): 191-201.

Bass, B. M., \& Avolio, B. J. 1990. The implications of transactional and transformational leadership for individual, team and organizational development. In R. W. Woodman \& W. A. Pasmore (Eds.), Research in organizational change and development, (4): 231-272. Greenwich, CT: JAI Press.

Beehr, T. A., Jex, S. M., Stacy, B. A., \& Murray, M. A. 2000. Work stressors and coworker support as predictors of individual strain and job performance. Journal of Organizational Behavior, 21(4): 391-405.

Beehr, T. A., Walsh, J. T., \& Taber, T. D. 1976. Relationship of stress to individually and organizationally valued states: Higher order needs as a moderator. Journal of Applied Psychology, 61(7): 41-47.

Bergeron, D. M. 2007. The potential paradox of organizational citizenship behavior: Good citizens at what cost? Academy of Management Review, 32(4): 1078-1095.

Biddle, B. J. 1979. Role theory: Expectations, identities, and behaviors. New York: Academic.

Biddle, B. J. 1986. Recent development in role theory. Annual Review of Sociology, 12(1): 67-92.

Bliese, P. D. 2000. Within-group agreement, non-independence, and reliability: Implications for data aggregation and analysis. In K. J. Klein \& S. W. J. Kozlowski (Eds.), Multilevel theory, research, and methods in organizations: Foundations, extensions, and new directions: $349-381$. San Francisco, CA: Jossey-Bass.

Bolino, M. C., \& Turnley, W. H. 2005. The personal costs of citizenship behavior: The relationship between individual initiative and role overload, job stress, and work-family conflict. Journal of Applied Psychology, 90(4): 740-748.

Bolino, M. C., Turnley, W. H., \& Bloodgood, J. M. 2002. Citizenship behavior and the creation of social capital in organizations. Academy of Management Reviewe, 27(4): 505-522.

Bollen, K. A. 1989. Structural equations with latent variables. New York: Wiley.

Bond, M. H., \& Hwang, K. 1993. The social psychology of the Chinese people. In M. H. Bond (Ed.), The Psychology of the Chinese People: 213-264. New York: Oxford University Press.

Brislin, R.W. 1980. Translation and content analysis of oral and written materials. In H. C. Triandis \& W. W. Lambert (Eds.), Handbook of cross-cultural psychology: 349-444. Boston: Allyn \& Bacon.

Chan, S. C. H. 2013. Paternalistic leadership and employee voice: Does information sharing matter? Human Relations, 67: 667-693.

Chan, S. C. H., Huang, X., Snape, E., \& Lam, C. K. 2013. The Janus face of paternalistic leaders: Authoritarianism, benevolence, subordinates' organization-based self-esteem, and performance. Journal of Organizational Behavior, 34(1): 108-128. 
Chen, X-P., Eberly, M. B., Chiang, T-J., Farh, J-L., \& Cheng, B-S. 2014. Affective trust in Chinese leaders: Linking paternalistic leadership to employee performance.Journal of Management, 40, 797-819.

Cheng, B. S., Chou, L. F., Wu, T. Y., Huang, M. P., \& Farh, J. L. 2004. Paternalistic leadership and subordinate responses: Establishing a leadership model in Chinese organizations. Asian Journal of Social Psychology, 7(1): 89-1 17.

Cheng, M-Y., \& Wang, L. 2015. The mediating effect of ethical climate on the relationship between paternalistic leadership and team identification: A team-level analysis in the Chinese context. Journal of Business Ethics, 129(3): 639-654.

Chou, W-J., Sibley, C. G., Liu, J. H., Lin, T-T., Cheng, B-S. 2015. Paternalistic leadership profiles: A person-centered approach. Group and Organization Management, 40: 685-710.

Dale, K., \& Fox, M. L. 2008. Leadership style and organizational commitment: Mediating effect of role stress. Journal of Management Issues, 20(1): 109-130.

De Cremer, D. 2006. Affective and motivational consequences of leader self-sacrifice: The moderating effect of autocratic leadership. Leadership Quarterly, 17(1): 79-93.

Eatough, E. E., Chang, C. H., Miloslavic, S. A., \& Johnson, R. E. 2011 . Relationships of role stressors with organizational citizenship behavior: A meta-analysis. Journal of Applied Psychology, 96(3): 619-632.

Ertureten, A., Cemalcilar, Z., \& Aycan, Z. 2013. The relationship downward mobbing with leadership style and organizational attitudes. Journal of Business Ethics, 116(1): 205216.

Farh, J. L., \& Cheng, B. S. 2000. A cultural analysis of paternalistic leadership in Chinese organizations. In J. T. Li, A. S. Tsui, \& E. Weldon (Eds.), Management and organizations in the Chinese context: 84-127. London: Macmillan.

Flood, P. C., Hannan, E., Smith, K. G., Turner, T., West, M. A., \& Dawson, J. 2000. Chief executive leadership style, consensus decision making, and top management team effectiveness. European Journal of Work and Organizational Psychology, 9(3): 401-420.

Foels, R., Driskell, J. E., Mullen, B., \& Salas, E. 2000. The effects of democratic leadership in group member satisfaction: An integration. Small Group Research, 31(6): 676-701.

Gong, Y-P., Huang, J-G., Farh, J-L. 2009. Employee learning orientation, transformational leadership, and employee creativity: The mediating role of employee creative self-efficacy. Academy of Management Journal, 52(4): 765-778.

Griffin, R. W. 1983. Objective and social sources of information in task redesign: A field experiment. Administrative Science Quarterly, 28(2): 184-200.

Hau, K. T., \& Marsh, H. W. 2004. The use of item parcels in structural equation modeling: Nonnormal data and small sample sizes. British Journal of Mathematical \& Statistical Psychology, 57(2): 327-351.

Hoel, H., \& D. Salin (2003). Organizational antecedents of workplace bullying. In S. Einarsen, H. Hoel, D. Zapf, \& C. L. Cooper (Eds.), Bullying and emotional abuse in the reorkplace: International perspectives in research and practice: 203-218. London: Taylor and Francis.

Hofstede, G. 1980. Culture's consequences: International differences in work-related values. Beverly Hills, CA: Sage.

Hunter, S. T., Bedell-Avers, K. E., \& Mumford, M. D. 2007. The typical leadership study: Assumptions, implications, and potential remedies. The Leadership Quarterly, 18(5): 435466.

Jackson, S. E., \& Schuler, R. S. 1985. A meta-analysis and conceptual critique of research on role ambiguity and role conflict in work settings. Organizational Behavior and Human Decision Processes, 36(1): 16-78.

Jex, S. M. 1998. Stress and job performance: Theory, research, and implications for managerial practice. Thousand Oaks, CA: Sage.

Jex, S. M., \& Beehr, T. A. 1991. Emerging theoretical and methodological issues in the study of workrelated stress. In G. R. Ferris, \& K. M. Rowland (Eds.), Research in Personnel and Human Resources Management Vol. 9: 311-365. Greenwich, CT: JAI Press Inc.

Johnston, M. W., Parasuraman, A., \& Futrell, G. M. 1989. Extending a model of salesperson role perceptions and work-related attitudes: Impact of job tenure.Journal of Business Research, 18(4): 269-290.

Kahn, R. L., Wolfe, D., Quinn, R., \& Snoek, J. D. 1964. Organizational stress: Studies in role conflict and ambiguity. New York: Wiley. 
Karambayya, R., Brett, J. M., \& Lytle, A. 1992. Effects of formal authority and experience on thirdparty roles, outcomes, and perceptions of fairness. Academy of Management Journal, 35(2): 426-438.

Katz, D., \& Kahn, R. L. 1978. The social psychology of organizations (2nd ed.). New York: Wiley.

Kelloway, E. K. 1998. Using LISREL for structural equation modeling: A researcher's guide. Thousand Oaks, CA: Sage.

Lankau, M. J., Carlson, D. S., \& Nielson, T. R. 2006. The mediating influence of role stressors in the relationship between mentoring and job attitudes. Journal of Vocational Behavior, 68(2): 308-322.

LePine, J. A., Podsakoff, N. P., \& LePine, M. A. 2005. A meta-analytic test of the challenge stressorhindrance stressor framework: An explanation for inconsistent relationships among stressors and performance. Academy of Management Journal, 48(5): 764-775.

Lewin, K., Lippitt, R., \& White, R. K. 1939. Patterns of aggressive behavior in experimentally created social climates. Journal of Social Psychology, 10: 271-301.

Li, Y., \& Sun, J-M. 2015. Traditional Chinese leadership and employee voice behavior: A cross-level examination. Leadership Quarterly, 26(2): 172-189.

Liang, S. K., Ling, H. C., \& Hsieh, S. Y. 2007. The mediating effects of leader-member exchange quality to influence the relationships between paternalistic leadership and organizational citizenship behaviors. Journal of American Academy of Business, 10(2): 127137.

Little, T. D., Gunningham, W. A., Shahar, G., \& Widaman, K. F. 2002. To parcel or not to parcel: Exploring the question, weighing the merits. Structural Equation Modeling, 9(2): 151173.

Lyons, T. F. 1971 . Role clarity, need for clarity, satisfaction, tension and withdrawal. Organizational Behavior and Human Performance, 6(1): 99-110.

Mackenzie, S. B., Podsakoff, P. M., \& Rich, G. A. 2001. Transformational and transactional leadership and salesperson performance. Journal of the Academy of Marketing Science, 29(2): 115-134.

Moorman, R. H. 1991. Relationship between organizational justice and organizational citizenship behaviors: Do fairness perceptions influence employee citizenship? Journal of Applied Psychology, 76(6): 845-855.

Muthén, B. 2011. Applications of causally defined direct and indirect effects in mediation analysis using SEM in Mplus. Submitted for publication.

Niehoff, B. P., \& Moorman, R. H. 1993. Justice as a mediator of the relationship between methods of monitoring and organizational citizenship behavior. Academy of Management Journal, 36(3): 527-556.

Organ, D. W. 1997. Organizational citizenship behavior: It's construct clean-up time. Human Performance, 10(2): 85-97.

Organ, D. W., Podsakoff, P. M., \& MacKenzie, S. B. 2006. Organizational citizenship behavior: Its nature, antecedents, and consequences. Thousand Oaks, CA: Sage.

Örtqvist, D., \& Wincent, J. 2006. Prominent consequences of role stress: A meta-analytic review. International Journal of Stress Management, 13(4): 399-422.

Pareek, U. 1976. Designing network for entrepreneurship development. Monograph, National Institute of Motivational and Institutional Development, Bombay.

Pearl, J. 2001. Direct and indirect effects. In proceedings of the seventeenth conference on uncertainty and artificial intelligence 41 1-420. San Francisco: Morgan Kaufmann.

Pelligrini, E. K., \& Scandura, T. A. 2008. Paternalistic leadership: A review and agenda for future research.Journal of Management, 34(3): 566-593.

Pelligrini, E. K., Scandura, T. A., \& Jayaraman, V. 2010. Cross-cultural generalizability of paternalistic leadership: An expansion of leader-member exchange theory. Group \& Organization Management, 35(4): 391-420.

Peterson, M. F., Smith, P. B., Akande, A., Ayestaran, S., Bochner, S., Callan, V., Cho, N. G., Jesuino, J. C., D’Amorim, M., Francois, P. H., Hofmann, K., Koopman, P. L., Leung, K., Lim, T. K., Mortazavi, S., Munene, J., Radford, M., Ropo, A., Savage, G., Setiadi, B., Sinha, T. N., Sorenson, R., \& Viedge, C. 1995. Role conflict, ambiguity, and overload: A 21-nation study. Academy of Management Journal, 38(2): 429-452.

Piccolo, R. F., \& Colquitt, J. A. 2006. Transformational leadership and job behaviors: The mediating role of core job characteristics. Academy of Management Journal, 49(2): 327-340. 
Podsakoff, P. M., Ahearne, M., \& MacKenzie, S. B. 1997. Organizational citizenship behavior and the quantity and quality of work group performance. Journal of Applied Psychology, 82(2): 262-270.

Podsakoff, P. M., MacKenzie, S. B., \& Bachrach, D. G. 2000. Organizational citizenship behaviors: A critical review of the theoretical and empirical literature and suggestions for future research. Journal of Management, 26(3): 513-563.

Podsakoff, P. M., MacKenzie, S. B., Lee, J-Y., \& Podsakoff, N. P. 2003. Common method biases in behavioral research: A critical review of the literature and recommended remedies.Journal of Applied Psychology, 88(5): 879-903.

Podsakoff, P. M., MacKenzie, S. B., Moorman, R. H., \& Fetter, R. 1990. Transformational leader behaviors and their effects on followers trust in leader satisfaction and OCB. Leadership Quarterly, 1(2): 107-142.

Pye, L. W., \& Pye, M. W. 2009. Asian power and politics: The cultural dimensions of authority. Cambridge: Harvard University Press.

Rast III, D. E., Hogg, M. A., \& Giessner, S. R. 2013. Self-uncertainty and support for autocratic leadership. Self and Identity, 12(6): 635-649.

Rizzo, J. R., House, R.J., \& Lirtzman, S. I. 1970. Role conflict and ambiguity in complex organizations. Administrative Science Quarterly, 15(2): 150-163.

Robert, C., Probst, T. M., Martocchio, J.J., Drasgow, F., \& Lawler, J. J. 2000. Empowerment and continuous improvement in the United States, Mexico, Poland, and India: Predicting fit on the basis of the dimensions of power distance and individualism. Journal of Applied Psychology, 85(5): 643-658.

Robins, J. M., \& Greenland, S. 1992. Identifiability and exchangeability of direct and indirect effects. Epidemiology, 3(2): 143-155.

Robins, J. M. 2003. Semantics of causal DAG models and the identification of direct and indirect effects. In P. Green, N. L. Hjort, \& S. Richardson (Eds.), Highly structured stochastic systems: 70-81. New York: Oxford University Press.

Saufi, R. A., Wafa, S. A., \& Hamzah, Y. Z. 2002. Leadership style preference of Malaysian managers. Malaysian Management Revieze, 37: 1-10.

Scandura, T. A., \& Graen, G. B. 1984. Moderating effects of initial leader-member exchange status on the effects of a leadership intervention. Journal of Applied Psychology, 69(3): 428-436.

Schuh, S. G., Zhang, X-A., \& Tian, P. 2013. For the good or the bad? Interactive effects of transformational leadership with moral and authoritarian leadership behaviors. Journal of Business Ethics, 116(3): 629-640.

Shenkar, O., \& Zeira, Y. 1992. Role conflict and role ambiguity of chief executive officers in international joint ventures. Journal of International Business Studies, 23(1): 55-75.

Singh, J. 2000. Performance productivity and quality of frontline employees in service organizations. Journal of Marketing, 64(2): 15-34.

Smircich, L., \& Morgan, G. 1982. Leadership: The management of meaning. Journal of Applied Behavioral Science, 18(3): 257-273.

Smither, R. D. 1993. Authoritarianism, dominance, and social behavior: A perspective from evolutionary personality psychology. Human Relations, 46(1): 23-43.

Song, L. J., Tsui, A. S., \& Law, K. S. 2009. Unpacking employee responses to organizational exchange mechanisms: The role of social and economic exchange perceptions. Journal of Management, 35(1): 56-93.

Tepper, B. J., \& Taylor, E. C. 2003. Relationships among supervisors' and subordinates' procedural justice perceptions and organizational citizenship behaviors. Academy of Management Journal, 46(1): 97-105.

Thompson, H. B., \& Werner, J. M. 1997. The impact of role conflict/facilitation on core and discretionary behaviors: Testing a mediated model. Journal of Management, 23(4): 583601 .

Tsui, A., Wang, H., Xin, K., Zhang, L., \& Fu, P. P. 2004. Let a thousand flowers bloom: Variation of leadership styles among Chinese CEOs. Organizational Dynamics, 33(1): 5-20.

Tubre, T. C., \& Collins, J. M. 2000. Jackson and Schuler (1985) revisited: A meta-analysis of the relationships between role ambiguity, role conflict, and job performance. Journal of Management, 26(1): 155-169.

Uhl-Bien, M., \& Maslyn, M. 2005. August. Paternalism as a form of leadership: Differentiating paternalism from leader-member exchange. Paper presented at the Academy of Management Annual Meeting, Honolulu, HI. 
Van Sell, M., Brief, A. P., \& Schuler, R. S. 1981. Role conflict and role ambiguity: Integration of the literature and directions for future research. Human Relations, 34(1): 43-71.

Vroom, V. H., \& Yetton, P. W. 1973. Leadership and decision making. Pittsburgh, PA: University of Pittsburgh Press.

Wang, A-H., Chiang, J. G-J., Tsai, C-Y., Lin, T-T., \& Cheng, B-S. 2013. Gender makes the difference: The moderating role of leader gender on the relationship between leadership styles and subordinate performance. Organizational Behavior and Human Decision Processes, 122(2): 101-113.

Wu, M., Huang, X., Li, C-W., \& Liu, W. 2012. Perceived interactional justice and trust-in-supervisor as mediators for paternalistic leadership. Management and Organization Revieze, 8(1): $97-121$.

Yukl, G. 2011. Contingency theories of effective leadership. In A. Bryman, D. Collinson, K. Grint, B. Jackson, \& M. Uhl-Bien (Eds.), The SAGE handbook of leadership: 286-298. Los Angeles: SAGE Publications Inc.

Zhang, Y., Tsui, A., \& Wang, D. X. 2011. Leadership behaviors and group creativity in Chinese organizations: The role of group processes. The Leadership Quarterly, 22(5): 851-862.

Yan Zhang (annyan.zhang@pku.edu.cn) is an associate professor in the School of Psychological and Cognitive Sciences and Beijing Key Laboratory of Behavior and Mental Health at Peking University. She received her $\mathrm{PhD}$ in organizational management from Peking University. Her research focuses on paradox management, leadership, team dynamics, and cross-cultural management.

Yun-Hui Xie (xieyunhui@gsm.pku.edu.cn) is a post-doctor in China Jianyin investment Limited Corporation. She received her PhD in Organizational Management Department from Peking University. Her research focuses on leadership, strategic human resource management, and team dynamics.

Manuscript received: October 7, 2014

Final version accepted: August 19, 2016 (number of revisions - 2)

Accepted by: (George) Zhen Xiong Chen 